\title{
Migration and Pentecostalism in a Mendicant Roma Community in Eastern Moldavia
}

\author{
Lehel Peti \\ Romanian Institute for Research on National Minorities \\ (Cluj-Napoca/Kolozsvár)
}

\begin{abstract}
The study analyzes the changes in the religious and social life of a Roma Pentecostal community in an ethnically mixed village, and the relationship between migration practices and conversion to Pentecostalism. In the first part of the study, the author presents the Roma community and outlines the circumstances under which Pentecostalism emerged among them. Thereafter, the two types of migration practiced by the Roma will be presented: migration focused mainly on northern European countries, based on panhandling, and migration aimed at longer term residence in the countries of Western Europe. The analysis points to the importance of foreign migration-related income in the changing situation of the Roma, as well as the role of the Pentecostal religion in the modernization changes that began in the Roma community.
\end{abstract}

Keywords: Roma, Moldavia, Pentecostalism, migration, panhandling

In this study, I examine the migration practices of a Pentecostal Roma community in an ethnically mixed village inhabited by Romanian and Roma populations, the related livelihood strategies, and the role of their Pentecostal faith in migration. ${ }^{1}$

In the first part of the study, I present the studied community, including how the Roma community's livelihood strategies were transformed after the most important social-historical turning points of the recent past (socialism and post-socialism). After that, I will present the two types of migration practiced by the Roma: one that is focused mainly on northern European countries and based on panhandling, and one that is aimed at long-term (but not definitive) residence in the countries of Western Europe (mainly England, France and Germany). As part of this, I will attempt to analyze the economic

${ }^{1}$ The research leading to these results has received funding from the European Research Council under the European Union's Seventh Framework Programme (FP7/2007-2013) / ERC grant agreement № 324214. The Hungarian version of this article was published in: Erdélyi Társadalom, Vol. XV. No. 1. 2017. 57-80. 
and social impacts of migration and the role that conversion to Pentecostalism played in it. The study illustrates the importance that income from foreign panhandling and other activities related to migration plays in the changing situation of the local Roma, and the role their conversion to Pentecostalism played in the economic and social processes that took place in the Roma community.

\section{OF URSĂRENI AND THE ROMA COMMUNITY IN GENERAL}

I started my fieldwork in 2013 in the Pentecostal communities of three neighboring settlements: a Roman Catholic majority (Csángó) village, a largely Orthodox Romanian village, and an ethnically mixed village with a solely Roma Pentecostal community. I consider these communities parts of a "network" because of the close relationship between them, the co-operation between their leaders, and their connected histories, etc. I visited the region a few times a year, and I usually visited all three communities. On a few occasions, however, I focused on one community more intensely. During the fieldwork, I interviewed members of different statuses, and attended ritual congregational meetings. The Csángó Pentecostal community leader, Anton, who commands a significant degree of authority within the "network," was helpful in building relationships.

Ursăreni ${ }^{2}$ is a village inhabited by Romanians and Roma. Looking at it from the expressway cutting across the Middle-Moldavian region of Romania, the settlement seems to be the same as most of the villages here: a vast majority of the houses displays the usual forms, materials and colors of Moldavian folk architecture. A multi-level, boarding house-sized building often protrudes from among the low houses with battered tin roofs, usually painted light blue or light brown. Among the farmhouses of unbaked mud brick, with a columned porch and a summer kitchen beneath the sloping roof, villas of this size are a fairly prominent expression of the new Romanian reality built by the dreams, motivations and ideas of the post-socialist generations partaking in the largescale migration that did not spare the eastern part of the country either.

As we leave the expressway, the villas disappear, and if one can still spot a few here and there, their singularity is conspicuous. Amidst the old houses, there will be some simple ones that preserve the old-fashioned design and are set apart from the old ones by their slightly bolder coloration, larger size, and new construction materials. Often you see boarded-up, abandoned homesteads that have long been unoccupied, while in other yards, besides the old farmhouses, there are also traces of new construction work. On the corners of smaller streets, there are glazed niches with tin roofs protecting Orthodox icons, surrounded by a low fence with a wicket gate here and there, while elsewhere there are covered draw-wheel wells decorated with icons, in some places with drinking troughs for draft animals. The main street that snakes on for kilometers ends in a fork, which is, in essence, the symbolic center of the village, with the mayor's office and one of the schools. While until the 1970s this part of the village was inhabited by Romanians only, it is now characterized by a mixed ethnic structure. Though slightly polarizing, it can be said that the livelier, busier homesteads with much of the new construction

\footnotetext{
${ }^{2}$ An alias, as are the names of the informants mentioned in the study.
} 
are inhabited mainly by Roma families, while in the summer it is conspicuous that the elderly people chatting on small benches near gardens and gates are mostly Romanian.

One of the streets passing through the central square leads to a remote, predominantly Roma-populated smaller village, while the other street snakes on for kilometers toward the forests on the remote hillsides. As we move away from the center, the street image changes. While earlier a more neglected, fence-less, rougher-looking homestead was the exception, on this segment of the road the poverty becomes more noticeable. From the narrow, asphalted street, a few narrow, neglected dirt roads branch off, only to turn into a dead end, or lead out into the meadows. Typical for this segment of the street, the dirt roads are lined with narrow, dilapidated houses often suggestive of unconcealed destitution. This is the Roma colony; during socialism (around the early/mid-1970s), the Roma lived exclusively on this colony, far from the village. Often the poorest Roma families live in these parts. With some 50 houses, the Roma colony remained the most destitute part of the village, despite major infrastructural improvements having been made over the past decade with EU funding. The local government paved the road leading to the colony, and provided public lighting along the bigger, car-driven street. Nonetheless, the conditions on the colony are destitute, and many Roma households do not even have electricity.

The profound poverty of the overwhelming majority of the local Roma is also supported by the data of ethnic demographic breakdown of social benefits. Of the 203 families receiving social benefits in the village, 175 families are Roma. ${ }^{3}$ Of the 190 families receiving family benefits and other social support, 80 families are Roma. Of the 250 families receiving heating subsidy, 110 are Roma families. ${ }^{4}$

In addition to high poverty, the natural population growth of the local Roma is very rapid. Official national censuses indicate a significant increase in the number of Roma (376 persons) and a significant decrease of the Romanian community (286 persons) in less than ten years.

Table 1. The ethnic distribution of the village based on the two most recent official national census data

\begin{tabular}{|c|c|c|c|c|}
\hline Census $^{5}$ & Romanian & Roma & Other + Unknown ethnicity & Total \\
\hline 2002 & 1923 & 854 & 4 & 2781 \\
\hline 2011 & 1637 & 1230 & 257 & 3124 \\
\hline
\end{tabular}

According to one of the councilors of the Roma party, the Roma number 1700. This estimate may be closer to the number of persons the local community considers to be

\footnotetext{
${ }^{3}$ Data from a survey conducted within the project called SocioRoMap. ISPMN, 2015.10.08. Among other things, the project called SocioRoMap included nationwide data collection at major Roma settlements via questionnaires coming from the mayor's offices. (Sociographic mapping of the Roma Communities in Romania for a community-level monitoring of changes with regard to Roma integration (SocioRoMap) - A project financed by the Norwegian Financial Mechanism 2009-2014 in the framework of "Poverty Alleviation in Romania" (RO25).

${ }^{4}$ Data from a survey conducted within the project called SocioRoMap. ISPMN, 2015.10.08.

${ }^{5} 2002$ and 2011 official national census data.
} 
Roma, despite the fact that fewer people declared themselves Roma in the census. Since the 2011 census was unable to determine the ethnic affiliation of the people residing abroad, and the statistics were supplemented by other existing sources (KIss 2012), the majority of people in the "other + unknown" categories of the statistics are presumably Roma. Taking into account the phenomenon well-known to Romanian researchers of Roma, i.e., that the Roma often conceal their ethnicity in a census, I consider the Roma party councilor's estimation of 1700 a realistic lower limit for the Roma.

Of the 36 children born in Ursăreni in 2013, 30 were Roma, while 44 of the 50 children born in 2014 were born in a Roma family. ${ }^{6}$

During the socialist era, many families of the rapidly expanding village moved to Moldavia and Dobrudja in hopes of a better living. These extensive, still active kinship systems play an important role in shaping the destiny of the Roma community of Ursăreni. According to reports, migration was the foremost strategy of emerging from the destitute local conditions during the socialist era, when several Roma settled in towns near and far, such as Oneşti, Adjud and Bacău. Some have succeeded in embedding themselves into the working class of the socialist industry.

The socialist urbanization wave affected the Romanians more intensively than the Roma. During this period, the Romanian community saw intensive migration, the target cities being Bucharest, Brașov, Sibiu and Bacău. This is when local Roma families began buying houses that were for sale outside the Pălămidă colony, "in" the Romanian-inhabited, actual village. A further decline in the number of Romanians was brought on after the regime change with the younger generation becoming migrant workers, which did not bode well for the possibility of their return. While even the Roma believe there will be an ethnic population exchange within the foreseeable future in the village, the possibility of returning to the village is not an attractive alternative for the Romanians (unlike the Roma).

\section{LIVELIHOOD STRATEGIES IN THE PAST AND TODAY}

Prior to the regime change, the local Roma worked on state farms, plantations and other farms in Dobrudja and Bărăgan. They usually departed for agricultural wage labor in the middle of spring, in April, and often returned to the village in the middle of winter, in December. In the local collective economy, the Roma have only found a small number of jobs, and those were mostly for men. State farms in the southern regions of Romania used canteens that fed the whole family to lure the Roma populations of the more remote regions into internal labor migration, thereby remedying the labor shortages of large farms.

The labor demands of the peasant farming that resurged after the regime change became a major employment opportunity for a significant part of the Roma. In the 2000s, the failure of Romanian small-scale farming became apparent, after which the aging Romanian population gradually abandoned peasant farming and transferred their lands to collective farms. Because of the mechanized work stages of the cultivation of large areas by these collectives, the demand for day-to-day work has drastically decreased, thereby causing a livelihood crisis in most Roma families on an already very fragile equilibrium level.

\footnotetext{
${ }^{6}$ Data from a survey conducted within the project called SocioRoMap. ISPMN, 2015.10.08.
} 
Some of the local Roma living in Ursăreni who do not travel abroad, or stay on the remaining peasant farms between trips, work as wage workers on the lands and vineyards. The most important work includes pruning, cluster thinning, tying grapevines, hoeing corn and grapes, harvesting corn and beans, etc. There are two forms of wage work: contract work and day labor. Work opportunities depending on the cycles of agricultural production generally affect the whole family during the season: teenagers are doing the same job as adults and are paid accordingly. All the family members get involved in the work - especially when doing a certain work phase - for a pre-negotiated amount. However, the income from agricultural wage labor is rather fluctuating, and it is not able to ensure the survival of a family for a longer term and at all times.

The patron-client system is still present in the case of still-operating peasant farms, and each Roma family is a long-standing and trusted workforce for Romanian families. The trust capital produced within this system also enables the exchange of work between the Roma and the Romanians. A 48-year-old Roma man, for example, had the same Romanian craftsman build two of his houses (which he paid for with money he raised by panhandling abroad), whom he previously helped plant 1000 vine stocks.

The other general strategy of income-generation, aside from social assistance, child support, and migration, is the collection of firewood, which is then sold to the Romanian villagers. As the village is not connected to the gas supply system, wood is the main fuel in the settlement. The money thus generated buys mostly grains of corn, as the staple of the family is the puliszka made from it.

Trading with walnuts is considered a seasonal income: the fruit of walnut trees growing in the fields and along roadsides is collected and cleaned, and the kernels are sold to traders who come to the village. In the autumn, whole families are engaged in walnut collection for weeks. The enormous amount of walnut shells scattered in the courtyards and filled into potholes like gravel offers a distinctive sight.

The majority of the Roma try to solve at least some of the family's food requirements at home, many of them raising poultry, a couple of piglets, hogs, even a couple of goats can be seen in some yards. Furthermore, the Roma living in the "village" cultivate vegetable gardens, some of them even planted garden vineyards. Two or three Roma families in the settlement operate a shop combined with a pub.

In addition to international labor migration, there is also an internal (domestic) labor migration that has adapted to the work phase needs of the agricultural year. This migration is focused mainly on the south-eastern regions of the country (Focşani), the main labor absorbers being the vineyards here that provide many months of work for many Roma people from Ursăreni.

In the local elections, the Roma party was able to add two representatives to the local council. One of them acts as a school mediator (mediator şcolar) on behalf of the Mayor's Office. A Swedish charitable organization operates an after-school program in the municipal building offered by the local government. The foundation has two employees and works closely with the Roma councilor and the regional Pentecostal pastor, a member of the "senior leadership" of the older of the two Pentecostal churches. The employees of the foundation commute to the settlement from the nearby city. According to the Roma councilor, the foundation is operated with the support of Swedish Pentecostal churches, and it has worksites in several countries (4-5 just in Romania), and their Romanian center is in Iaşi. The foundation undertook the feeding, clothing and remedial education 
of up to 50 Roma children in need. One of their projects aims to renovate the homes of those children in need. At the time of my research, they were working on three houses, aiming to modernize 30 houses. According to the Roma councilor, the aim of the nonprofit organization in Ursăreni is to curb the panhandling-focused migration abroad by trying to improve the local living conditions of the Roma.

In addition to the non-profit organization with foreign support, a foundation in Bacău also operates a project focusing on the integration of Roma children (Valoare plus), which provides supplementary education for Roma children in grades 6-8. Children participating in the project are given a donation package.

\section{THE ROLE OF FOREIGN PANHANDLING IN ROMA LIVELIHOOD}

In the livelihood of the Roma, the most important role is played by the income related to foreign migration. Following the country's accession to the EU, villagers begun to leave in large numbers to go panhandling primarily in northern European states, mainly in Norway and Sweden, but also in France and Finland. They stayed a few weeks at a time, two months at the most, several times during the year. The majority of the Roma families of Ursăreni is habitually engaged in panhandling abroad. Several family members would travel abroad, but not necessarily at the same time. This is necessary so that the elderly and the children of extended families would not be left on their own, as well as to ensure that the households keep running. Since the goal of panhandling is to buy a plot and build a house in the village, the head of the family sometimes skips his foreign trip to continue the construction.

In an interview, one of the non-Roma leaders in the Pentecostal network stressed the organized nature of panhandling: community leaders have a say in who travels and who stays at home. In his opinion, they may even pay each other for the better panhandling spots. Regarding the organized aspect of panhandling and whether they are paying for better spots, a survey conducted in capital cities of Scandinavian states has concluded that the implication of criminal organizations in panhandling is a myth, and although there were some instances of paid panhandling spots, it was by no means the typical pattern (DJUvE et al. 2015:80). Community leaders are actually church leaders, or those close to them, involved in church life through their various functions. The Csángó community leader, however, emphasized that its organization, according to his own wording, takes place at the "caste level," in this sense independent of the Roma Pentecostal organization.

\footnotetext{
“They left, and one said to the other: 'Come here, come here!' But to be honest, they sorted out the spots between themselves. So that they could sell them to another that wants a spot. 'This one will go to the village, you stay there, if you want his spot, give me I don't know how many crowns!'”(April 25, 2016)
}

The Ursăreni Roma themselves never indicated in their interviews that the Pentecostal community leaders had a say in their panhandling trips. In organizing the trips, family-

\footnotetext{
${ }^{7}$ Translated from Romanian, as are all quotes from informants of the study.
} 
level decisions and information within the kinship and acquaintance networks play a significant role. ${ }^{8}$

The most common way to travel is to use a local travel company specializing in seasonal travel aimed at panhandling. This business was founded by a local Roma who transports the mendicants on minibuses mainly to Sweden, Norway, and Lille in France. There are minibuses leaving for Norway and Sweden twice a week. Generally, about 10 to 13 people can travel per trip, for a predetermined price.

As other studies analyzing the labor migration patterns of Roma living in extreme poverty have also pointed out, an important component of migration is borrowing for the usury (KISS - PETI 2015; KIsS 2014). It is not uncommon that the Ursăreni Roma living from day to day turn to a usurer for the money needed to travel. Those involved in the research mentioned a non-Pentecostal Roma person as being a loan shark. The usurious interest rate of the loan increases with the time elapsed since it was borrowed.

Many of the traveling Roma do not have the money they need to travel, and according to a sort of loan system, the transporter lets them travel even without payment, collecting their dues on the return trip from the money they made panhandling. A one-way trip to Lille costs 100 euros, to Sweden slightly more than 100 euros. This Roma entrepreneur owns a fancy villa.

Some of the Roma traveling on their own resources travel in their own cars. In that case, they pool their money to pay for gasoline. There are also some who travel by regular Romanian buses.

The Ursăreni Roma making a living by panhandling say they are able to earn 400-500 crowns (a little more than 50 euros) per day, which is more than four times the day-labor wage at home. According to Daniel, ${ }^{9}$ one of the non-Roma community leaders of the Pentecostal network mentioned earlier, the average daily earnings of mendicant Roma abroad are around 30-40 euros, less often up to 50 euros per day. Their daily nutrition costs less than 10 euros. The survey ${ }^{10}$ conducted in Scandinavian capitals on Romanian Roma has shown significantly lower income: for example, in Stockholm, daily earnings from combined income averaged just 14.5 euro (DuUve et al. 2015:68).

“(...) So it pays off. They put it in their purse ... come and buy all the houses of the Romanians there" (April 25, 2016).

A young couple I talked to right before they headed out said that it is not uncommon to establish a relationship with local residents who provide them with food, and there are even some who let them use their bathrooms occasionally.

A 52-year-old Roma man estimates that in order to travel to Sweden for a few months, one needs a minimum of 200 euros, which, as I have already mentioned, some of the Roma in Ursăreni can only get by taking out a loan. The man, formerly a member of the

\footnotetext{
${ }^{8}$ The research team that conducted a survey in the capitals of Scandinavian countries reported consistent results (DJUVE et al. 2015:76).

${ }^{9}$ Presbytery leader of the Pentecostal community of the "network" functioning in an Orthodox community.

${ }^{10}$ The authors use the term 'street worker' for those Romanian Roma whose main incomes include begging, pile-bottle collecting and other 'informal street work' (DJuve et al. 2015:7).
} 
leadership committee of the Pentecostal Church, has ten children and no job. His main income is from panhandling in Sweden. He says he goes to Luleå, a Swedish town on the northern coast of the country, where some 35 people travel from his village alone. The Roma of Ursăreni panhandle at different spots in the city, mostly as singing beggars. His spot is at the city market. He reports that the mendicant Roma often sleep in their cars; most recently, the Red Cross provided them with a shelter (a huge room where everyone has their own mattress), where they also get free meals, but local churches support them, too. He says that since he has been going to Sweden, he was able to start building a house.

Panhandling-focused migration is essential for the livelihood of the majority of local Ursăreni families. ${ }^{11}$ In addition to the everyday cost of living, the ritual costs of these Roma families are also covered by the money obtained through panhandling. According to a lengthy video of a Pentecostal wedding uploaded to a community video sharing portal (recorded by one of the participants and in which I recognized some of my informants), the public gifting of the young couple by shouting out the sum was made with a variable amount of Swedish crowns.

Some of the extended families spend part of the money they have panhandled on purchasing land and building a house in the village. The Roma family that used their panhandled savings to start a business by opening a convenience store on the Roma colony is considered an exception.

However, the long-term viability of this strategy is questionable. The head of a Roma family regularly panhandling in Norway reported in the summer of 2016 that, due to the "migrant situation" in Europe, the profitability of foreign panhandling has greatly declined.

\section{LONG-TERM MIGRATION}

In addition to the panhandling migration that focuses mainly on Sweden and Norway, there is a migration practice that is aimed at long-term residence. Families that mostly migrate to England, Spain, France, and recently to Germany, strive to establish a longterm lifestyle in a Western European country, unlike the Roma living from panhandling and regularly commuting between their home village and the major cities of northern Europe. The councilor of the Roma party estimates that there are approx. $700^{12}$ Ursăreni Roma families which a few years ago settled down in Western European countries for an indefinite period. The most important guarantee of maintaining their lifestyle abroad is to get into - and stay in - the social security system of these foreign states. Some members of these families even earn an income outside the social care system. As a matter of fact, long-term migration consists of a combination of different livelihood strategies. The combination of strategies aims to solidify the chances of their survival. I talked to Roma whose relatives collected scrap metal in London, others were doing low-key jobs,

\footnotetext{
${ }^{11}$ Based on a survey conducted on the Romanian Roma who sought their livelihood in the capitals of the Scandinavian countries in 2014 involving 1269 people, and by building on the results of additional fieldwork and interviews, the research team found that in addition to begging, the Romanian Roma are involved in a diverse range of activities related to the informal economy (DJUVE et al. 2015:55).

${ }^{12}$ However, I find this number to be exaggerated.
} 
working as school traffic wardens or doormen, etc., and some even made a living by panhandling. These strategies may alternate even in the case of one person, depending on their current options. According to the Roma councilor, this pattern works primarily for the Roma who have moved to Germany, England and France.

According to the Roma party councilor, the Ursăreni Roma with many children have a higher chance of accessing the foreign social care system. It could take several months, up to half a year, for a migrant family to take care of the necessary bureaucracy. The family must have adequate reserves to cover this period without income. This amount is estimated by the representative of the Roma party to be around 2-3,000 euros. A common pattern of acquiring the necessary funds is panhandling in Sweden and Norway. The main guarantee for obtaining the missing amount is provided by the intra-kinship loan system. The best chance for this comes from a member of the kinship network that has been living abroad for some time, for he is the main source of information needed for surviving abroad and provides the most important help in managing affairs abroad. According to my informant, in Germany, which is the latest migration destination for the Ursăreni Roma, the family allowance is 420 euros per child, while in Romania the same is slightly less than 10 euros. A condition of the child benefit is for the children to attend school. Families with multiple children have higher chances when applying for foreign child benefits, and when successful, they can achieve a more stable income level. Child benefits allow them to rent accommodations with a comfort level that is far above the destitute circumstances at home.

Compared to the panhandling families commuting from Ursăreni, this strategy entails a greater risk and more personal and family energy expenditure (e.g., language learning, administration, remedial job training, etc.), but if successful, the volume of material gain is also higher, and the increase in the standard of living is also significant when compared to that of the village.

It was primarily the Roma families with better financial resources that engaged in longterm migration. ${ }^{13}$ They are aware of the precarious chances of a long-term stay or of ultimate settlement, so even in their case, as preparation for a crisis situation and as a backup security strategy, the attempt to build an existence in their home village is still present.

\section{THE ECONOMIC AND SOCIAL IMPACTS OF MIGRATION}

As I mentioned, the main goals of both types of migration are to buy land and build houses in the village. With their savings, they buy abandoned Romanian homesteads. The price of a plot in need of demolishing or renovating is 20-23,000 euros in the areas closer to the main road (that is, not on the colony), while a plot with a better location and a "neat" house could reach the market value of 45,000 euros.

The frequent seasonal migration of the Roma has a negative impact on the chances of schooling their children. Roma families living temporarily in Western countries for some time have been schooling their children. Schooling seems to be an important component of integrating into the social security system of their host countries. As opposed to the

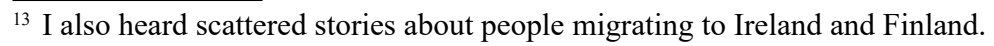


majority of Ursăreni Roma families engaged in a temporary, one- or two-month-long panhandling migration, Roma families residing abroad for a period of 3-4 years and temporarily returning to the village cannot get their children integrated in the local school system. Besides the many pedagogical and social reasons for this, the biggest obstacle is bureaucratic: parents cannot register their children in local schools for lack of documents, which once again produces a high level of illiteracy among the Roma, even exceeding that of their parents. ${ }^{14}$

According to the Roma councilor, the views of the Romanian community regarding the relative economic successes of the Roma are mixed. In some cases, it activates prejudices, while others rejoice in the fact that the Roma are investing in an economically and socially "depressed" village in the region and lessening the extent of social exclusion through migration. The councilor believes that migration has an emancipatory effect on the Roma:

"Look, the Gypsy got to go abroad, he came home, bought a house. Some people (...) there are some who think like racists. Others praise them: 'Bravo, look, they pulled out of it, they are no longer who they were (...) poor. They pulled out of it, they deserve all due respect, they bought a house, fixed up their house, became good farmers...' They often (...), now they (...), this migration was good for them. That is, the emancipation. They also saw how (...) what it was like abroad, how to dress, how to talk...” (Ursăreni, July 19, 2016.)

\section{THE ROLE OF PENTECOSTALISM IN THE LIFE OF THE ROMA OF URSĂRENI}

In Ursăreni, there are two Pentecostal communities. There are different narratives about the history of the Ursăreni Roma's conversion to Pentecostalism. Although I have tried to find out about this issue in several interviews with various members of the community, as well as in conversations with "external" Pentecostal leaders well acquainted with the situation of the Roma, I could not clarify all the details of the story in a completely reassuring way. Reticence, exaggerated expression in the interest of confirming one's opinion instead of facts, and mistrust stemming from the sensitivity of the issue could have all contributed to this. Despite all this, the next scenario seems to be the closest to the truth.

The formation of the first Pentecostal Roma community dates to the early 1990s. ${ }^{15}$ Like most Roma, a man who had a good reputation in the Roma community and his family had been involved in seasonal, months-long labor migration in the early 1990s. The family converted to the Pentecostal religion on a farm in southern Romania. Returning to the village, the head of the family commenced his proselytizing missionary work, which resulted in several families converting to the Pentecostal religion.

\footnotetext{
${ }^{14}$ The survey conducted among Roma migrants in the capitals of Scandinavian countries has measured very low educational achievement: $11 \%$ of Romanian Roma working in Stockholm completed some kind of school education, in Oslo the rate of completed education was around $40 \%$, while in Copenhagen 45\% (Djuve et al. 2015: 41). At the same time, the same survey has shown a high level of illiteracy, the rate of which was always higher in the case of women (see Djuve et al. 2015: 41).

${ }^{15}$ I briefly described the history of the community in a previous article (PETI 2016).
} 
The first assemblies of the small Pentecostal community were held in family homes. The gradually growing community was embraced by the leaders of the oldest congregation of the microregion, who supported the construction of the first Pentecostal church in Ursăreni in 1998. The growth of the community was accompanied by constant conflicts among the local Pentecostal Roma elite. The non-Roma leaders were able to establish a relative equilibrium in the congregation split into two parties by assigning a deacon from each camp a function. The division of the hierarchy of the congregation in this way was accepted by the regional Pentecostal organization as it is, in the interest of maintaining a stronger influence over spontaneously organizing congregations. Such reconciliation of the congregation's interest groups has ensured the relative equilibrium of the congregation for several years. Meanwhile, the ownership of the church was "turned over" by one of the leadership consortia to the Regional Pentecostal Organization in Suceava, ${ }^{16}$ thereby gaining control over it. Although this Roma leadership has had its powers consolidated for some time through the influence of the regional organization, it has led to the deepening of conflicts within the congregation.

Using this discontent, a member of the Roma elite who had previously lost out and been marginalized in the battle for Pentecostal Church leadership positions, started the construction of a new Pentecostal church, bringing the opposition leaders of the old congregation and a significant part of the discontented membership with him. The second church, operating since 2014, was built from donations from Roma Pentecostal communities abroad, members of which hailed from Ursăreni. According to the reports, the son of a person who was one of the wealthiest people in the Roma community played a decisive role in collecting donations to build the church from Pentecostal churches in Norway, Netherlands and Sweden. According to Daniel, who is familiar with the local conditions, ${ }^{17}$ he claimed that they were discriminated against and expelled from their church. I also heard it from Daniel that the son of the current presbyter participated in labor migration to Sweden about 15 years ago, and his knowledge of the local conditions led to the first wave of panhandling migration to Sweden (Sweden later became a transit country for the mendicant Roma of Ursăreni). This person played a leading role in organizing the initial travels of the Roma, but Csángó community leader Anton emphasized that the travels took place mainly within the intra-kinship system of mutual assistance. I also heard an opinion (from a middle-aged woman in the congregation in question) that the son of the presbyter was in contact with the local Pentecostals at the time of his stay abroad, and a major private donation of one of them greatly contributed to the building of the church. Although I cannot verify the truth of these statements, it is clear that the Roma family that successfully contributed to the construction of the second church, to the acquisition of an official operating license, and to organizing the new community made significant efforts to acquire one of the most important leadership positions of the Roma community in Ursăreni.

\footnotetext{
${ }^{16}$ Although ownership of the church is in the hands of the communities, the other two communities of the "network" that I have been studying (the Csángó, and the one in the village with the Orthodox majority) also obtained the legitimization of leadership status from the Suceava regional organization, thus belonging to that organization.

${ }^{17}$ Leader of the Pentecostal Community functioning in the village inhabited by mostly Orthodox Romanians.
} 
The new church began its operation in the Pentecostal movement with the approval of the Roma Pentecostal Movement, an organization with legal autonomy within the Suceava area, headquartered in Braşov (Uniunea Adunărilor lui Dumnezeu Penticostale Apostolice Romilor din România). According to the Statute of the National Pentecostal Organization, the Roma Pentecostal Movement is part of the Pentecostal movement, equal with the regional organizations. Based on my information so far, it is not clear what in fact is the relationship of this legally autonomous body to the national Pentecostal organization. This institutional structure seems to be quite independent in Romanian Pentecostalism, seeking to consolidate the various Roma movements with varying degrees of autonomy, providing them with a legal framework. ${ }^{18}$ To formally function as a religious community is, in principle, allowed by Romanian law, but its implementation would encounter many obstacles in practice. The regional and local officials connected to the national Pentecostal organization mainly through the regional organizations see the new institution - organized primarily along the lines of the Roma elite's interests and system of relations - as competition. This is indicated by the fact that non-Roma Pentecostal leaders within the "network" (like Anton, the local Csángó community leader, Daniel, the presbyter and leader of the Pentecostal congregation in the Orthodox majority village, and the district pastor) spoke of it as a separate structure organized along ethnic lines (discussing it in connection with the Roma discrimination discourse). The independence of the Roma congregation is also indicated by the fact that the abovementioned leaders referred to it as the Liga Romilor (Roma League).

The following functions can be found in the studied congregations: community leader (elected by the congregation, primarily responsible for secular matters, but also for observing the ritual order of religious gatherings and establishing the order of speakers), presbyter (not subject to religious knowledge, assigned by the regional organization, ${ }^{19}$ responsible for the most important rituals - wedding, funeral, baptism, etc.), deacon (also a function approved by the regional organization, primarily ministering to the ritual order of church events, preaching, administering the sacrament, attending to religious matters upon the instruction of the presbyter, etc.). Less significant and primarily secular functions are treasurer and censor (economic supervisor) elected by the community.

In addition to the "official" positions based on the legitimacy of organizational and community elections, the function of the proroc (seer, prophet) is based on a particular religious/magical legitimacy. This role also functions as an official role within the national Pentecostal Church (there are prorocs officially recognized by the Church, their activity governed by a statute of the national organization), but in most Pentecostal communities, prorocs operate in an independent, informal way and with varying degrees of legitimacy depending on the community. In the Roma community I studied, the locally, or at most regionally, significant function of proroc was held by four persons: two men and their wives.

The current leadership of the local Pentecostal churches reflects the political/power relations within the community. These are not independent of extended family/kinship coalitions either. The leadership of the two Roma churches is in open conflict with

\footnotetext{
${ }^{18}$ For example, the Rugul Aprins (Ponoara) and the Toflean Pentecostal Roma community. The latter may have been legally transferred to the Bucharest branch.

${ }^{19}$ Local leaders refer most often to the national organization as cult (in this context: organization).
} 
each other. The membership of the former church that became inactive as a result of resentment and disregard was successfully attracted by the religious entrepreneur who built the temple, as well as the two new church officials, the community leader, and the deacon who had served in this function in the former church. Extended family and kinship coalitions also played a role in which church the Pentecostal Roma would be joining. The new church has approx. 50-60 members. ${ }^{20}$ The founder of the new Pentecostal church has become a presbyter, administering the sacrament, performing weddings, baptizing, and so on. ${ }^{21}$

The two rival Pentecostal churches in the studied settlement are connected to the Pentecostal movement through two different relation systems and organizational structures. One through the regional (but not specifically Roma) organization of the national organization of Pentecostalism, while the other through a fairly autonomous (but not regional) structure that consolidates Roma movements.

\section{MIGRATION AND DIASPORA COMMUNITIES}

Ada I. Engebrigtsen describes the role of extended family networks in the case of Romanian Roma "street workers" 22 panhandling in Oslo (ENGEBRIGTSEN 2005:3). Maintaining kinship-based relations is also very important to the Roma of Ursăreni. This also played a role in the evolution of the migration patterns of the Ursăreni people after the regime change. The development of expatriate communities was determined by information gathering along the lines of kinship, mutual assistance, and emigration to the same places.

The importance of family networks has been highlighted by the research conducted with combined methods in the capitals of Scandinavian countries (DJUVE et al. 2015:74). However, this research has shown that, in spite of close cooperation in the practical organization of travel and living abroad, "these groups should not be understood as economic units. While group members might eat or drive together, we were consistently told that if income is shared, it is mainly between spouses" (DJUvE et al. 2015:76).

Migration along kinship networks resulted in new and relatively stable communities of Ursăreni people in London and Lille. The Roma migrating to the big cities of Western Europe initially lived in illegal caravan camps. They bought used caravans for a few hundred euros, setting them up near stations, bridges, motorways, etc., joining other smaller or larger camps, or forming new ones. During this time, they were mainly trying to make a living by panhandling or collecting scrap metal. By now, several families have been able to enter the local social care system.

The non-Roma leader of the Pentecostal group in the Orthodox majority village has in this period visited the Ursăreni Pentecostal Roma living in camps abroad on several occasions. In the initial phase of international migration, during the "caravan period,"

\footnotetext{
${ }^{20}$ Based on information provided by the leader of this congregation. At the church events I attended in the spring/summer, usually $30-35$ people were present.

${ }^{21}$ Most of this information comes from an April 25, 2016 interview with Daniel, the presbyter of the Pentecostal community in the Orthodox village.

${ }^{22}$ Concept of the author, Ada I. Engebrigtsen.
} 
community leaders have not yet emerged, thus the Romanian leaders feared that, in the absence of leaders, they would lose the close to 50 Pentecostal believers living abroad for extended periods. The community was held together by organized missionary visits. During his missionary visits, the man who led the central congregation of the Moldavian Pentecostal network provided essential ritual services (baptisms, blessing of newborns, weddings, healing rituals, administration of sacraments), and he occasionally administered new baptisms, too. Some of the people being baptized were not from Ursăreni but were among the Romanian Roma living in caravan camps. According to the said presbyter, on one occasion he baptized 15 persons, of whom seven were from Ursăreni. The rite of baptism took place in the Atlantic Ocean. In this initial phase, the gatherings were said to be held in a larger caravan. Some of the Roma working as singing beggars formed an improvised band, thus the songs were performed to the accompaniment of an accordion.

"They had their spots, their caravans. On corners, by railways, motorways or roads. They spread out all the way from here to the inn. Caravans were lined up side by side. That is, they bought them for 350 euros, a caravan that they had (...) You know what a caravan is. A small, two-person, six-person caravan placed on two of these planks. I also lived in a caravan, that's how I served" (April 25, 2016).

The only organized institutional framework for Roma communities living abroad is the Pentecostal Church. They rented buildings in London and Lille, where regular Romanian adunare (gatherings) are taking place. The expatriate congregations also produced their own religious leaders. These congregations formally belong to one of the Roma branches of the Romanian Pentecostal Movement, their religious leaders approved by one of these organizations. These communities number around 200-300 people. Their membership consists exclusively of Romanian Roma. A large number of members come from Ursăreni or are members of families that belong to the kinship systems of Ursăreni or have come into the relation systems through the Pentecostal religion. In the selection of leaders, the size of their kinship group is as important as their aptitude (due to contact capital, political support).

Examples of the establishment of a Pentecostal diaspora community are not limited to Ursăreni. From the Orthodox majority village, which was one of the communities I have been studying, several families moved to Palma de Montechiaro in Sicily, where they founded an independent Pentecostal congregation. For their ritual community events, they rented a church, which is alternately used by an Italian and the Romanianspeaking community. The leaders of this community come from the village with the Orthodox majority and were given authority to fulfill ecclesiastical functions by the Suceava regional organization.

\section{Migration and the non-institutional forms of Pentecostalism}

Besides the prorocs functioning outside the official institutional framework of the Ursăreni Pentecostal Roma and exhibiting signs of religious specialization, there are also persons who are unusually well-versed in the interpretation of dreams and visions 
or have a better-than-average understanding of possession. Unlike the prorocs, they do not practice their skills in a systematic and institutionalized way, but rather they are employed in neighborly and kinship circles and for occasional situations.

Prayer for solving each other's problems is a matter of daily practice, and even so, some people's prayers are attributed greater power. The magical use of the power of prayer can thus explain the event I witnessed after one of the assemblies. Following the assembly, a young Gypsy woman intensely gesticulating and raising her voice pulled aside the wife of Anton, the Pentecostal community leader. The event took place in Ursăreni, in the newer Pentecostal church. ${ }^{23}$ When we later traveled back to the Csángó village together and I asked her what that was about, she told me that the young woman had asked her to pray for her, as her panhandling signs in Italy contained lies. The admission of this "sin" to the community leader's wife was similar to the "mărturisire" (witnessing, confession) that was used with the proroc and which sought to obtain God's forgiveness and help, and thus avoid misfortune. The young woman believed the prayers of the Pentecostal community leader's wife were "more powerful" than the "simple" prayers of those in her own kinship system.

Although on the level of designation exorcism and the ability to have visions are often referred to as a special gift of the Holy Spirit, there are overlaps in exercising these "abilities". The two male prorocs in Ursăreni, whose activities are well known to the whole community, also told a number of exorcism stories in which they themselves participated in the role of the exorcist. It is an important coincidence that the emergence of the second proroc couple as prorocs is connected to the opening of the second Pentecostal church in 2015, when they became the prorocs of this congregation.

The basis of the distinction between prorocing/divination (prorocire) ${ }^{24}$ and visions is the way in which the Holy Spirit communicates with the believers. In the case of divination, the communication is a direct message, even if it is in the form of glossolalia (speaking in tongues). The person who receives the divination in a glossolalia form understands exactly what the message is. In the case of the gift of a vision (as in the case of dream interpretations), the form of communication is metaphorical: the person receiving it is not a direct mediator but a specialist in the process of interpretation. The "gift of vision" can also play a role in exorcisms: those who receive it may either confirm or question the success of exorcism. As the proroc of the newer church who also does exorcisms said, a person with the gift of vision can see (or else feel) whether all the demons had left the possessed or not:

- Can you see when the demon leaves the person? Or how can one know that God's work has been accomplished?

- It depends on whether someone has a vision or has the gift of vision. He could see the moment he closed his eyes, the moment he felt it leave during prayer. He either sees or feels what is leaving. Whether all the demons left, all the demons exited, or there was still something

\footnotetext{
${ }^{23}$ Anton and his wife had participated on other occasions in events at the church in Ursăreni, but this time they were there to support my research.

${ }^{24}$ In this writing, I use the Csángó's etic terminology to name this rite containing divinatory and possession elements (that is what the Csángó Pentecostal group belonging to the network calls this ritual) (PETI 2016).
} 
in there. And then there must be one who has the gift of vision. I cannot just go there with my gift of divination, or another who has a different gift (...) of demons. This is also a gift, very (?), some possess all the gifts (perhaps), or just one gift (...) The gift of the Holy Spirit is manifested in visions and in all kinds of ways. It must be there. There must be a seer, so as not to (...) miss a demon that has not been released, and you say that you are free and the visions (...) but his visions suggest that there is still something in that person. This is how (the Holy Spirit) showed me, he shows me! - so says the person who has this gift (...) (Ursăreni, July 17, 2016).

The Pentecostal religiousness engaged in divination and exorcism and founded on the interpretation of subjective religious experiences (dream, vision) is also relevant for the groups functioning abroad. The religious/magical notions and exercises that have less legitimacy in the institutional hierarchy of Pentecostal religiousness are also reproduced in diaspora communities. Since these communities also require these forms of Pentecostalism, they had Florin, a man who has been a proroc in the Ursăreni community for a while ${ }^{25}$ travel to them on several occasions. Florin's magical activities include revealing the causes of illness, praying for the healing of the patient, discovering the outcome of future events, etc. One time, for example, a Roma woman sought him out about the fate of her son imprisoned abroad. According to Florin, the Lord revealed through the gift of divination that the woman's son would be released in that year. Florin said that this has really happened, and the grateful woman phoned him to thank him for the fulfilled prophecy.

One time when I visited him in April 2016, it was two weeks after he returned from Duisburg, Germany, where he was providing various ritual services. He said that he went to Duisburg upon the invitation of a community of Romanian Roma (mainly from Timişoara, Arad, Bucharest), his ticket and other expenses paid by this community. Florin's "magical service package" (healing, illness interpretation, and prophecy - in Ursăreni, they call this practice "prorocire," divination - and performing exorcisms) had no problem fitting into the non-doctrinal ritual system of the Pentecostal community in Germany.

According to Florin, during his recent trip to Germany two weeks before I talked to him, a Roma family living in Germany for a long time and owning their own home asked for his help. One of the family's children was in the hospital with a brain tumor, where they prayed for it under Florin's guidance. According to Florin, the child was miraculously cured by the prayers, and the doctors who were present found the tumor gone.

\section{THE PENTECOSTAL CHURCH'S STANCE ON PANHANDLING}

According to the official Pentecostal discourse, panhandling is a sin: the leaders of the network urge its punishment, and there is even a symbolic punishment for it. However, talking to non-Roma functionaries in the network, it turned out that they were perfectly aware of how much the livelihood of the Roma depended on this practice, and regarded it as a "pardonable," "venial sin." The punishment is being set aside (suspension), which is brought into effect by the community leader. Daniel, who served them for

\footnotetext{
${ }^{25}$ An alias, as are all the names of other people in the study.
} 
three months, insisted on using suspension for "panhandling and singing". In addition to the discriminatory and shaming function of being set aside or seated in the back, the punished person cannot take on any ritual role in the assembly (adunare) during this period (speaking, witnessing, loudly praying in front of the community, and in the case of women, performing one's "own song" in front of the community, etc.). The punished person's membership in the Pentecostal community is, in fact, symbolically placed in a temporary, suspended status, the length of which may range from three to six months, depending on the severity of the sin. One of the 40 -year-old women participating in the study said that the person so punished "loses his rights before God". (April 26, 2016)

Daniel also said that one time when he went on a missionary visit of a caravan camp in Lille during the "caravan period," several of the recently baptized Roma there believed that he who panhandled was with Satan, and the waves of the Danube would take him as punishment, and he had no right to participate in assemblies. Daniel dispelled these "false teachings", baptized them, and told them that when they returned to Romania, their punishment would be three months of being set aside (April 25, 2016).

\section{Livelihood strategies of a Roma family and their relationship with Pentecostalism: a case study}

Most of the strategies typical of the majority of the Ursăreni Roma can be found in the Dionisie family, and I will try to briefly present these in the following.

I met Dionisie and his wife Mirela in 2014, and I have visited their home many times since. On those occasions, I spent a whole day with them, getting to know several members of the extended family, many of whom I interviewed. My first encounter with Dionisie turned out to be quite memorable. I was walking with Anton, the leader of the Csángó Pentecostal community, in a remote corner of Ursăreni, when we came upon a wagon pulled by a donkey carrying dried corn stalks and a weathered man on a scooter clinging to it. The owner of the scooter, a middle-aged, brown-skinned man with bright blue eyes who laughed often (exposing a couple of his gold teeth) was Dionisie. Dionisie and his wife lived at this time on the Roma colony. They have six adult children and 27 grandchildren. Their seventh child died at the age of seven because of a severe cold.

In the family, the woman was the first to convert. According to her, she was religious already. Her closer relationship with orthodoxy came after the death of her seven-yearold child. That is when she started going to church and seeking solace in religion. She told me that her child died in the hospital, without a candle. An Orthodox woman advised her to light a candle at Easter, to provide her dead son light in the afterlife.

“(...) my son died (...) my seven-year-old son died and (...) I started going (...) to (...) the church, to (...) the Orthodox church. And what the world did, I did it too. I paid for a mass, I stood there (...) I filled the candle holder with candles, kissed the icons, the Virgin Mary. Aaa..., my child died in the hospital, without a candle. And (...) somebody, the women said that at Easter I should light, every Easter light a funeral candle, and that I should fill the candle holder with candles. So that the child might have light there (...) and I went to $\mathrm{P}$, the temple in $\mathrm{P}$, and bought a large funeral candle, a prepared cake, and donated it to the church for them to burn it (...) at the time of the resurrection. I do not even understand it myself. (...) While the resurrection is taking 
place, let the funeral candle burn, to provide light for the child. After I converted, I realized that it was (...) unnecessary. That there was no point in what I did (...) I was in the dark, I was (...) I think I was blind, I was not myself (...)" (Ursăreni, April 25, 2016).

As she explained, she often observed people returning from the assemblies seeming happy. On such occasions, Mirela was seized by a longing mixed with curiosity, wanting to be a part of it. Around that time, a Pentecostal Roma told Mirela about one of his dreams. According to that person's story, he saw a dry well in Mirela's house, from which he heard the voice of a child crying for help. Then he dropped a rope and pulled out the child, after which the well filled with water. The person who dreamed this claimed that the child in the dream was Mirela. Also around this time, another Pentecostal believer visited her to tell her of a dream about her. In this dream, Mirela was dressed in white as she was singing in the middle of the congregation. According to Mirela, these emotionally significant dream stories, the symbolism of which she had identified with her vacant life, the need for change, had prompted her to start visiting the Pentecostal assemblies and to convert. When faced with a dilemma of lifestyle change, Pentecostal Roma women often turn to dream interpretation.

Mirela's conversion resulted in a conflict in her family. Her husband did not appreciate the woman's ever stronger connection to the Pentecostal Church, which, on the one hand, brought on a change in the woman's behavior, but also resulted in her having spent a lot of time at assemblies held several times a week, as well as informal religious gatherings organized by families or neighborhoods that often lasted well into the night. Because she had a nice voice, the woman became one of those who publicly performed religious songs at church meetings. ${ }^{26}$ Despite her husband's continuous squabbling (which she tried to ignore, even though she'd never budged before), she persisted in her faith. On one occasion, when she was coming home from a church meeting, her husband who was working at home threw a cob at her in his anger. The woman interpreted her husband's angrier than usual behavior as Satan's ire for having taken the sacrament at the assembly. Seeing the woman's perseverance and fasting, after a while, the husband also converted.

"One day I took the sacrament, and he was working on a Sunday. Found some work for a Sunday. He dismantled the cart, he was oily up to his neck, and he was repairing it, hammering it and ... and I came from the church where I took the sacrament. When I walked through the gate, he picked up this big cob, and when he threw that cob at me, I defended myself. Because if I did not defend myself, it would have hit my head. (...) And I stood there because what ... 'what does Satan do?' I say. Because I took the sacrament, that's why he does this. I went behind the house, knelt and cried ... and ... prayed. He came after me, caressed me, 'forgive me', he said. Because he saw that ... before I was a believer, I kept mouthing off to him. He'd say a (bad) word, I'd say two. He swore, I swore back. He'd insult my mother, I'd insult his. I did not shut up. But after seeing that I did not retort, that I cried, that I prayed, that I fasted ... He saw the change, and he went and gave himself (to God)" (Ursăreni, April 25, 2016).

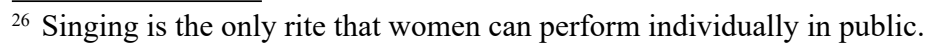


Dionisie and Mirela's fixed monthly income consists of social benefits of 200 leu (less than 50 euros). Dionisie has been permanently employed once in his life, which lasted three years, with one of the sanitation companies in the nearby city. For a significant part of the year, the couple works on the fields of local Romanian farmers, mainly in vineyards, within the framework of patron-client relations. Dionisie also chops wood and owns some land, where he, too, has planted a vineyard. Being converted Pentecostals, they do not drink wine, so they sell the crops instead. They keep some chickens, some goats, a couple of piglets. Like many other local Roma, they also do "walnutting." In addition to their own collecting, they buy large batches of walnuts in shell, which are then broken, cleaned and sold as nutmeat, mainly to traders who come to the village. The main income of the family comes from panhandling in Sweden and Norway. They travel abroad from their own resources.

One of their six children has lived in France for a long time with his own large family. He works as a part-time doorman, as well as collects scrap metal with his own car. In the meantime, the father of six managed to get social benefits amounting to 2,500 euros a month. Their other children live in the village, like most, mainly panhandling abroad, or taking on seasonal work in the wider region (mainly in Moldavia). Many of their close relatives also live abroad. One of Mirela's sisters lives in Spain, another in England, and two of her brothers live in Germany.

In 2015, they purchased a mud brick house on its own plot and with a large garden around the house in the "best" part of the village, close to the main road. In the same year, they started construction on two new houses on the plot - one for themselves, the other for their son living in France.

The family's sound economic state and prosperity as compared to their previous situation are attributed to the effect of Pentecostalism. According to the woman, after her conversion, they managed to build their house on the Roma colony. They bought a car for one of their sons, helped him get his driver's license, and even bought two cows.

\footnotetext{
"But God worked! During these two years we built this house, from August to autumn the house was raised and covered. We finished the house in the second year. But where the money came from, I do not know, I do not know where the moneys came from. After that, we bought the car for the boy, paid for the driver's license, bought two cows. It came, you know, I give my children bread like a dream, I did not know where it (the money) came from, I asked the question, 'Who is helping us, who is providing for us?' Because before we were believers, the money was never enough. We had a million or two, but where did it go, what did we do, because we did not buy anything" (Ursăreni, April 7, 2014).
}

For Mirela, it is not only the dreams full of religious significance and guidance so important to the Pentecostal Roma, but also the advice mediated by the prorocs that play a major role in making a big decision. Mirela's narrative reveals that in difficult times, she often turned to the prorocs. She asked for their help even when, caring for her invalid mother, she felt discouraged about her desperate situation. The proroc predicted her mother's miraculous recovery, which according to Mirela was fulfilled.

According to another story, their son and his family decided to stay in France during the extremely difficult period following their emigration (the caravan period, memorialized by several family photos) after the Holy Spirit messaged him through a 
proroc that his prosperity would come in a foreign country. With the current prosperity of her son, Mirela considered the "prophesy" confirmed, just as she herself sought out Martin, the most prominent proroc of the network, who lived in the Orthodox community. At that time, Mirela had doubts about going to panhandle in Sweden. Her doubts came from the ambivalent community perception of panhandling. The proroc affirmed her intent to travel abroad, saying God would help her on her journey. After that, Mirela traveled with her husband to Sweden, where they did indeed get lucky. According to her, in two months, she and her husband earned so much money that they could buy a plot in the village and get started on the new construction. This story of Mirela points to her ambivalent attitude to panhandling within Pentecostalism.

“... I wanted to go to Sweden, too, but I could not. It was like something was holding me back like that ... no ... I was thinking I was going to that country to commit a sin; I cried and I went to Brother Martin (the proroc). To the old man. (...) And ... 'Brother, I have something (to confess) before God, brother.' I had this trouble, wanted to see if God would let me go ... to that country. But I did not tell that to the brother. 'I have a request before God, brother.' And he said, 'You have your mind on making a trip,' he said. 'Go ... go, for God's blessing will be on the journey which you will undertake.' And God allowed me to go. And there I earned money, brother ... We bought these two houses, these houses here, we made nearly a billion" (Ursăreni, April 7, 2014).

The couple travels abroad to make money 2-3 times a year, each time spending 1-2 months. One year, when his son lived in a caravan camp in France, Dionisie collected scrap metal with his son.

During their longest stay in Sweden (before which Mirela visited a proroc), they panhandled on weekdays, and on Sunday they went to the local church. Dionisie has occasionally taken on minor temporary jobs, such as repainting the exterior wooden cover of houses.

The city's charitable church organizations provided temporary accommodations and care for the Romanian and Bulgarian Roma panhandling at various points of the city. The system that emerged was that the 10-bed accommodation was occupied by the Romanians for a week, and the following week they switched places with the Bulgarian beggars. Dionisie and his wife slept at the station during those times, while they said that the Bulgarians, when it was not their turn, slept in their own cars. It was the charitable church organizations that initiated contact with the Roma beggars, their representatives seeking them out at their begging places and inviting them to their temples. On such occasions, they were able to clean up and were fed, too. Through the family, one of the churches organized a fundraising event for the Roma of Ursăreni, after which their representatives traveled to Ursăreni, and with the consent of Dionisie's family, they produced for the fundraising campaign an artfully executed photo and video composition set to music of grandchildren living in poverty.

Although Pentecostal ethics suggests that begging, as I have just mentioned, is at best an ambivalent action, they do comply with some of the rules of Pentecostal ethics while exercising it. Mirela said she panhandled with Romanian songs. With the Romanian and Romani-language religious songs that she used to perform in the church; in her telling, she never begged. As she said, she regards it as a serious sin; she would only sing the religious songs to herself, when nobody passed before her, and merely for religious purposes. 
In the preceding, I presented the livelihood strategies of a Roma family in Ursăreni. The strategies followed by the family essentially illustrate the most important changes of the recent past in the Roma community in Ursăreni: turning to Pentecostalism and the pursuit of migration-related incomes following EU accession, resulting in the emergence of two main types of migration - a temporary migration focused on panhandling, and a longer term migration involving emigration. I presented the importance of Pentecostalism in the maintenance of migration (family relationships, the community organizing role of the Pentecostal Church abroad, contact with other churches), and I presented the mentality-forming role of religion in conducting economic activities (e.g. turning to religious specialists when making relevant decisions) and organizing consumption in their pursuit of acting in accordance with their religious worldview.

\section{CONCLUSION}

In this paper, I attempted to analyze the migration patterns of a Roma community in Moldavia, the related livelihood strategies, and the relationship between Pentecostalism and migration.

Although panhandling in Sweden and Norway is certainly one of the most important sources of income for the Roma of Ursăreni, the situation of some of the Roma improved because, for various reasons, the Romanian population represents an ever-decreasing competition for them, and in the symbolic sense, they are increasingly giving up on the village. The situation of some of the Roma has therefore improved not necessarily because they made a lot of money through panhandling, but because due to the aging Romanian community that has been steadily emigrating since the socialist era, the decrease of their previous positions enabled the Roma to buy their lands and houses in the village. Their participation in migration, however, was a prerequisite of the Roma population's moving from the colony to the actual village.

In parallel with migration and moving into the village, a community-organizing project that profoundly changed the mentality and attitudes of the Roma community was taking place: their conversion to the Pentecostal religion. Both Roma and non-Roma consider the most powerful achievement of the Pentecostal religion to be the endorsing of a wholesome lifestyle, a normalized relationship with the family, the community and the outside world, moderation, and a mentality that encourages the overcoming of the "uncivilized" image of the pre-conversion Roma.

In addition to encouraging a more rational economic behavior and lifestyle, Pentecostalism has created an institutional community framework for the Roma both at home and abroad. The mobility of individuals and families depend on these institutions. In parallel with the Pentecostal religious project, there was a fierce competition between the local elites, from which the diaspora communities abroad were not exempted. The Pentecostal religion has consolidated leadership positions within the community and has created new statuses.

Pentecostalism plays an important role in the establishment and maintenance of relations within the transnational framework between the Roma of Ursăreni and the Roma who emigrated from Ursăreni. For the Roma that were integrated through Pentecostalism, the "ritual revitalization" (FoszTó 2009) inherent in Pentecostalism (in 
addition to rites of passage, participation in rituals connected with conversion, illness, and various crisis situations) created new occasions for extending and strengthening family and kinship networks. The "official rituals" of Pentecostalism were initially ministered during the missionary visits of the network's Pentecostal leading elite. The needs of expatriate communities with an independent leadership have brought to life the phenomenon of the religious specialists functioning in the gray zone of Pentecostal religiosity: the "traveling prorocs" engaged in divination, faith healing, and exorcism. However, through their support, expatriate Pentecostal communities also influence the power relations of the local Roma elite, as was the case with the second Pentecostal church in Ursăreni.

As well as being a stimulant of modernization, Pentecostalism has been dedicated to demonstrating the Roma's willingness to civilize and modernize. ${ }^{27}$ In terms of a wholesome lifestyle (e.g. alcohol, spousal infidelity, ban on gambling, the ethos of a converted person vis-á-vis the extreme consumption of pleasures, etc.), the Pentecostal religion contributed to the changing of the patterns in which the Roma community thought of itself. In this way, through a favorable macro-economic condition (free migration available through the country's 2007 EU accession and the related new resources: panhandling-focused migration and long-term, but not necessarily permanent foreign residence), Pentecostalism also fulfills the role of an unprecedented explanation system that unlocks/displays the economic successes affecting part of the Roma community on an ideological level.

Although the Pentecostal churches in which the Roma of Ursăreni are assembled (the two local churches, as well as the ones in Lille and London) do not consider a part of the Roma community to be Pentecostal as per religious criteria, there is still a nonformal and fundamentally non-religiously motivated loose attachment to the Pentecostal Church on the part of these Roma.

The effect of the Pentecostal mentality thus affects the entire Roma community.

Pentecostal religiosity exists in syncretic unity with pre-conversion Roma religious notions and practices (for example, regarding divination notions and practices, as well as notions of possession), thus passing down or renewing traditional notions.

\section{REFERENCES CITED}

DJuve, Anne Britt - Friberg, Jon Horgen - Tyldum, Guri - Zhang, Huafeng

2015 When Poverty Meets Affluence. Migrants from Romania on the Streets of the Scandinavian Capitals. 1-163. Fafo: Rockwool Foonden. http://www.fafo.no/ images/pub/2015/954-innmat-trykk.pdf (accessed April 6, 2017).

\footnotetext{
${ }^{27}$ In a previous article, I touched upon the presentation of Roma conversion as a "civilizing project" (PETI 2017), comparing it to the role of Pentecostalism in a Transylvanian Hungarian-speaking Roma community as observed by Dénes Kiss, which he synthesized in the context of the "thematization of Pentecostal Ethics" (Kiss 2009). Its essence is that the converted Roma emphasize their community's willingness to civilize/modernize (and its results) through their conversion.
} 


\section{ENGEBRIGTSEN, Ada}

n.d. Invading Our homelands. New beggars in the streets of Oslo. (manuscript) https://www.academia.edu/28523905/Invading_our_homelands_new_ beggars_in_the_streets_of_Oslo (accessed April 2, 2017).

FoszTó, László

2009 Ritual Revitalisation after Socialism. Community, Personhood, and Conversion among Roma in a Transylvanian Village. Halle Studies in the Anthropology of Eurasia, Volume 21. Münster: LIT Verlang.

KIss, Dénes

2009 Romii din Herculian și rolul religiei penticostale în viața lor comunitară [The Roma of Magyarhermány and the Role of Pentecostalism in Their Community Life]. In KIss, Tamás - FoszTó, László - FLECK, Gábor (eds.) Incluziune și excluziune. Studii de caz asupra comunităților de romi din România [Inclusion and Exclusion. Case Studies of Roma in Romania]. 119-143. Cluj-Napoca: Editura Institutului pentru Studierea Problemelor Minorităților Naţionale Kriterion.

2014 Benyomások a székelyhídi romák vallási életéről [Impressions of the Religious Life of the Roma of Székelyhíd]. Szocioblog. A BBTE Szociológia Tanszékének blogja. http://bbteszocioblog.blogspot.ro/2014/08/benyomasokszekelyhidi-romak-vallasi.html (accessed December 9, 2015).

KIss, Tamás - PeTi, Lehel

2015 A romák munkaerőpiaci helyzete és politikai mobilizációja [The Labor Market Situation and Political Mobilization of the Roma]. Community study: Ázog. INTEGRO - Integrare prin formare și mediere POSDRU/165/6.2/S/140487/ manuscript.

PETI, Lehel

2016 A Szentlélek ajándékai és karizmatikus rítusok egy moldvai kistérség pünkösdi közösségeiben [Gifts of the Holy Spirit and Charismatic Rituals in the Pentecostal Communities of a Moldavian Micro-region]. In Hesz, Ágnes - Pócs, Éva (eds.) Orvosistenektöl a hortikulturális utópiáig. Studies from the Carpathian Basin Catchment Area [From Divine Doctors to a Horticultural Utopia. Studies from the Carpathian Basin]. 319-351. Budapest: Balassi Kiadó. Vallásantropológiai tanulmányok Közép-Kelet-Európából 2.

2017 A pünkösdizmusra való áttérés okai és funkciói egy moldvai roma közösségben [Causes and Functions of Converting to Pentecostalism in a Roma Community in Moldavia]. In edition.

TransindeX - Kiss, Tamás

2012 Légből kapva. 1,2 millió embert berajzoltak a statisztikákba [Out of Thin Air. 1.2 Million People Pnserted into Statistics]. Kertész Melinda interjúja Kiss Tamás szociológussal. Transindex news portal, July 5, 2012 http://itthon. transindex.ro/?cikk=20718 (accessed December 9, 2015). 
Lehel Peti (1981) Full-time researcher at the Romanian Institute for Research on National Minorities (Cluj-Napoca/Kolozsvár) and part-time lecturer at the Department of Hungarian Ethnography and Anthropology (Babeș-Bolyai University). Research interests: the social and religious aspects of Moldavian and Transylvanian villages. He is the author of several research articles, resp. book chapters. He has published two books: A moldvai csángók vallásossága. Hagyományos világkép és modernizáció [The Religiosity of the Moldavian Csángós. Traditional Worldview and Modernization] (2008, Budapest), and $A$ moldvai csángók népi vallásosságának imagisztikus rítusai [The Imagistic Rituals of Popular Religion in Moldavian Csángó Villages] (2012, Cluj-Napoca). E-mail: petilehel@yahoo.com 